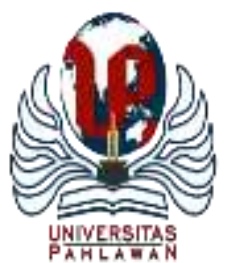

Edukatif : Jurnal Ilmu Pendidikan Volume 3 Nomor 6 Tahun 2021 Halm 4108 - 4117 EDUKATIF: JURNAL ILMU PENDIDIKAN

Research \& Learning in Education

https://edukatif.org/index.php/edukatif/index

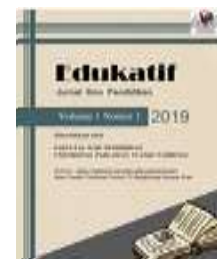

\title{
Pengaruh Pengalaman Praktik Kerja Industri (Prakerin), Informasi Dunia Kerja dan Motivasi Memasuki Dunia Kerja terhadap Kesiapan Kerja Siswa SMK
}

\author{
Agia Seriana Yusadinata ${ }^{1}$, Amir Machmud ${ }^{2}$, Budi Santoso ${ }^{3}$
}

Universitas Pendidikan Indonesia, Indonesia ${ }^{1,2,3}$

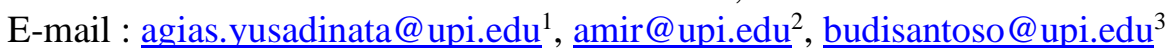

\begin{abstract}
Abstrak
Penelitian ini bertujuan untuk mengetahui pengaruh pengalaman praktik kerja industri, informasi dunia kerja dan motivasi kerja terhadap kesiapan kerja siswa kelas XII program keahlian otomatisasi tata kelola perkantoran SMK Negeri se-kota Serang. Populasi dalam penelitian ini adalah siswa kelas XII program keahlian otomatisasi tata kelola perkantoran di SMK Negeri se-kota Serang sebanyak 434 siswa dengan jumlah sampel sebanyak 208 siswa. Metode penelitian yang digunakan adalah metode Explanatory Survey dengan teknik pengumpulan data menggunakan kuesioner. Pengolahan data menggunakan teknik analisis data regresi linier berganda dengan bantuan program IBM SPSS for Windows 25.0. Hasil penelitian menunjukan bahwa gambaran umum tentang pengalaman praktik kerja industri, informasi dunia kerja, motivasi kerja dan kesiapan kerja siswa kelas XII program keahlian otomatisasi tata kelola perkantoran SMK Negeri se-kota Serang termasuk kedalam kategori tinggi. Pengalaman praktik kerja industri, informasi dunia kerja dan motivasi kerja memiliki kontribusi pengaruh terhadap kesiapan kerja siswa sebesar 56,10\%. Simpulan dalam penelitian ini adalah terdapat pengaruh yang positif dan signifikan antara pengalaman praktik kerja industri, informasi dunia kerja dan motivasi kerja terhadap kesiapan kerja siswa baik secara parsial maupun simultan.
\end{abstract}

Kata Kunci : Pengalaman praktik kerja industri, Informasi dunia kerja, Motivasi kerja siswa dan kesiapan kerja

\begin{abstract}
This study aimed to find out the effect of industrial work practice, a world of work information, and work motivation experiences on the work readiness of class XII students of automation and office management expertise program at Vocational High School (SMK) in Serang City. The population in the study was 434 students in class XII of the automation and office management expertise program at SMK in Serang City, and the number of samples was 208 students. The research method used the Explanatory Survey method with data collection techniques using questionnaires. The data processing used multiple linear regression analysis techniques with the assistance of the IBM SPSS program for Windows 25.0. The study's results showed that the overview of industrial work practice, the world of work information, motivation and readiness of working experiences of class XII students of automation and office management expertise program at SMK in Serang City included in the high category. The experiences in the industrial work practice, the world of work information, and work motivation had a 56.10\% contribution impact on the students' work readiness. This study concluded that there were positives and significant effects between the industrial work practice, world of work information, and work motivation experiences on the students' work readiness either partially or simultaneously.
\end{abstract}

Keywords: Industrial work practice experience, the world of work information, students work motivation, and work readiness.

Copyright (c) 2021 Agia Seriana Yusadinata, Amir Machmud, Budi Santoso

$\triangle$ Corresponding author

Email : agias.yusadinata@upi.edu

DOI : https://doi.org/10.31004/edukatif.v3i6.1318

ISSN 2656-8063 (Media Cetak)

ISSN 2656-8071 (Media Online) 
4109 Pengaruh Pengalaman Praktik Kerja Industri (Prakerin), Informasi Dunia Kerja dan Motivasi Memasuki Dunia Kerja terhadap Kesiapan Kerja Siswa SMK - Agia Seriana Yusadinata, Amir Machmud, Budi Santoso

DOI: https://doi.org/10.31004/edukatif.v3i6.1318

\section{PENDAHULUAN}

Pengajaran erat kaitannya dengan pengakuan kualitas Sumber Daya Manusia (SDM). Karena melalui pengajaran, HR dapat menambah informasi, kapasitas dan pengalaman yang dapat membantu untuk memiliki pilihan untuk bersaing dalam memenuhi kebutuhan. Sarana yang dapat diakses dalam mempersiapkan (SDM) menjadi pelamar tenaga kerja yang berbakat adalah melalui sekolah profesi. Sekolah Menengah Kejuruan (SMK) merupakan landasan edukatif yang merencanakan untuk menyiapkan SDM yang siap bekerja sesuai dengan keunggulan dan penguasaannya masing-masing. Keberadaan lembaga pendidikan SMK dalam mempersiapkan siswanya untuk menjadi calon tenaga kerja yang terampil masih perlu ditingkatkan, karena belum semua dari lulusan SMK dapat sepenuhnya terserap kedalam dunia kerja, fenomena ini ditunjukkan dengan data yang diperoleh dari Badan Pusat Statistik (BPS) yang menunjukkan bahwa lulusan SMK menjadi salah satu penyumbang terbesar pengangguran pada Tingkat Pengganguran Terbuka (TPT), dimana data ini menunjukkan bahwa daya serap lulusan dari sektor SMK ke dalam dunia kerja yang semakin menurun ditunjukkan dengan meningkatnya jumlah pengangguran dari sektor lulusan SMK bisa dilihat Tabel 1. berikut ini:

Tabel 1. Data Tingkat Pengangguran Terbuka (TPT)

Menurut Pendidikan Tertinggi yang Ditamatkan Tahun 2020

\begin{tabular}{|c|c|c|c|}
\hline \multirow{2}{*}{ No. } & \multirow{2}{*}{$\begin{array}{l}\text { Pendidikan Tinggi } \\
\text { Yang Ditamatkan }\end{array}$} & \multicolumn{2}{|l|}{2020} \\
\hline & & Febuari & Agustus \\
\hline 1 & SD & 1.006 .744 & 1.410 .537 \\
\hline 2 & SLTP & 1.251 .352 & 1.621 .518 \\
\hline 3 & SLTA Umum/SMU & 1.748 .834 & 2.662 .444 \\
\hline 4 & $\begin{array}{l}\text { SLTA } \\
\text { Kejuruan/SMK }\end{array}$ & 1.443.522 & 2.326.599 \\
\hline 5 & Akademi/Diploma & 267.583 & 305.261 \\
\hline 6 & Universitas & 824.912 & 981.203 \\
\hline Total & & 6.542 .947 & 9.307 .562 \\
\hline
\end{tabular}

Fenomena ini menjadi sangat ironis dan tidak sejalan dengan tujuan SMK karena tujuan dari lembaga pendidikan SMK belum sepenuhnya tercapai, dimana seharusnya melalui lembaga pendidikan ini para lulusannya bisa langsung terserap kedalam dunia kerja. Dilansir dari media Indonesia.com menurut Dirjen Pendidikan Dasar dan Menengah (Dikdasmen) Kemendikbud Hamid Muhammad mengungkapkan bahwa adanya empat hal yang mempengaruhi peningkatan pengangguran dari lulusan SMK salah satunya adalah persoalan kualitas lulusan yang tidak sesuai dengan standar yang dibutuhkan oleh industri. Masalah kualitas lulusan erat kaitanya dengan masalah kesiapan kerja siswa dimana ciri-ciri siswa yang memiliki kesiapan kerja menurut (Brady, 2009) menyebutkan "kesiapan kerja mengandung enam unsur yaitu responsibility, flexibility, skills, communication, self view, healty dan safety". Unsur-unsur tersebut mencerminkan kualitas diri yang dimiliki dari siswa dengan kesiapan kerja. Permasalahan dunia kerja yang belum sepenuhnya dapat menyerap siswa dapat disebabkan oleh beberapa faktor diantaranya faktor eksternal dan faktor internal. Menurut (Sukardi, (2003) berpendapat bahwa, "Faktor-faktor yang mempengaruhi kesiapan kerja meliputi faktor intern dan faktor sosial. Faktor intern yaitu yang bersumber pada diri individu meliputi kemampuan intelegensi, bakat, minat, nilai, sikap, kepribadian, hobi atau kegemaran, prestasi, keterampilan, penggunaan waktu senggang, aspirasi dan pengetahuan sekolah, pengetahuan tentang dunia kerja, pengalaman kerja, 
4110 Pengaruh Pengalaman Praktik Kerja Industri (Prakerin), Informasi Dunia Kerja dan Motivasi Memasuki Dunia Kerja terhadap Kesiapan Kerja Siswa SMK - Agia Seriana Yusadinata, Amir Machmud, Budi Santoso

DOI: https://doi.org/10.31004/edukatif.v3i6.1318

kemampuan dan keterbatasan fisik, masalah dan keterbatasan pribadi. Sedangkan faktor sosial meliputi bimbingan dari orang tua, teman sebaya, dan keadaan masyarakat sekitar".

Pengalaman Kerja Siswa (prakerin) disebutkan menjadi salah satu faktor yang dapat mempengaruhi kesiapan kerja siswa. Menurut (Bukit, (2014)menjelaskan bahwa, "dengan adanya prakerin maka siswa akan memiliki keahlian dan pengalaman kerja yang dapat mempermudah siswa dalam mencari pekerjaan". Menurut Johnson, (2007) menyatakan bahwa pengalaman memunculkan potensi seseorang. Potensi penuh akan muncul bertahap seiring berjalannya waktu sebagai tanggapan terhadap bermacam-macam pengalaman. Sejalan dengan hasil penelitian yang dilakukan oleh Penelitian oleh (Ahkyat, 2019) praktik kerja industri berpengaruh positif terhadap kesiapan kerja siswa. Dengan demikian semakin baik praktik kerja industri yang dilakukan mahasiswa maka kesiapan kerja mahasiswa juga akan semakin baik. Adanya hubungan praktik kerja industri dengan kesiapan kerja siswa ditunjukkan dengan hasil penelitian yang dilakukan oleh (Hilmi \& Lukmantoro, 2019) penelitian ini menunjukkan hasil bahwa terdapat hubungan yang tinggi antara pengalaman praktik kerja lapangan dengan kesiapan kerja siswa. Namun berbeda dengan hasil penelitian yang ditemukan oleh (Novitasari, 2013) yang menunjukkan hasil bahwa terdapat hubungan yang rendah antara pelaksanaan program pengalaman lapangan terhadap kesiapan siswa menjadi calon karyawan atau pegawai. Hal ini menunjukkan tidak sepenuhnya praktik kerja lapangan atau industri dapat memberikan tingkat hubungan yang sama terhadap kesiapan kerja.

Faktor eksternal lainnya yang dapat mempengaruhi kesiapan kerja siswa adalah informasi dunia kerja. Menurut (Winkel \& Sri, 2007)Informasi tentang dunia kerja yang mencakup semua data mengenai jenis-jenis pekerjaan yang ada dimasyarakat, mengenai tahap dan jenis jabatan, sistem klasifikasi jabatan dan prospek masa depan berkaitan dengan kebutuhan ril masyarakat akan jenis/corak pekerjaan tertentu. Informasi dunia kerja dapat mempengaruhi proses pengambilan keputusan siswa dalam menentukan tujuan arah karirnya pada masa mendatang dan informasi yang diterima oleh siswa diharapkan bisa dijadikan sebagai suatu gambaran dalam melihat peluang-peluang yang ada dan dapat membantu siswa untuk menghadapinya. Sumber informasi dunia kerja dapat diperoleh dari berbagai sumber, baik yang disediakan oleh sekolah maupun dari luar sekolah. Bagi calon tenaga kerja lulusan dari SMK, memiliki informasi dunia kerja yang banyak dapat memberikan kemudahan dalam mengetahui kondisi dunia kerja. Hal ini dapat menjadikan suatu dorongan agar para lulusan SMK dapat lebih meningkatkan tingkat Readiness dalam dirinya sendiri. Menurut hasil penelitian dari (Kusnaeni \& S, 2016) menunjukkan bahwa informasi yang diperoleh siswa dari berbagai sumber dan pihak dapat mendukung dalam mempersiapkan diri untuk bekerja sehingga dapat membantu siswa dalam mempersiapkan diri memasuki dunia kerja. Namun berbeda dengan hasil penelitian yang dilakukan oleh (Komang, 2014) bahwa adanya perbedaan informasi yang diperoleh siswa dalam meningkatkan pemahaman diri terhadap kesiapan kerja. Hasil penelitian menunjukkan bahwa adanya perbedaan hasil yang signifikan dibuktikan dari hasil rata-rata pemahaman informasi yang diberikan sekolah terhadap kesiapan kerja siswa kelompok eksperimen dan siswa kelompok kontrol.

Selain praktik kerja industri dan informasi dunia kerja yang dapat mempengaruhi kesiapan kerja, faktor motivasi juga perlu mendapatkan perhatian penuh. Menurut(Hasibuan, 2007) mengemukakan bahwa motivasi penting karena dengan motivasi diharapkan setiap individu karyawan mau bekerja keras dan antusias untuk mencapai produktivitas kerja yang tinggi. Menurut (Uno, 2014) motivasi timbul karena adanya keinginan untuk melakukan kegiatan, adanya dorongan dan kebutuhan melakukan kegiatan, adanya harapan dan citacita, adanya lingkungan yang baik, adanya kegiatan yang menarik dan adanya penghargaan dan penghormatan atas diri. Tingkat pengaruh motivasi pada kinerja seseorang tergantung dari seberapa besar tingkat motivasi yang dimiliki dan seberapa banyak intensitas motivasi yang diberikan. dengan adanya motivasi kerja siswa yang tinggi diharapkan dapat memberikan dampak yang baik pada kesiapan kerja siswa. Menurut hasil penelitian yang dilakukan oleh (Ahmad, 2020) menunjukkan bahwa adanya hubungan yang positif dan 
4111 Pengaruh Pengalaman Praktik Kerja Industri (Prakerin), Informasi Dunia Kerja dan Motivasi Memasuki Dunia Kerja terhadap Kesiapan Kerja Siswa SMK - Agia Seriana Yusadinata, Amir Machmud, Budi Santoso

DOI: https://doi.org/10.31004/edukatif.v3i6.1318

signifikan antara motivasi kerja siswa terhadap kesiapan kerja siswa. Semakin baik motivasi kerja yang dimiliki dan diberikan kepada siswa, maka siswa akan memiliki kesiapan kerja yang baik. Berbeda dengan hasil penelitian yang dilakukan oleh (Kian, 2014) yang menyebutkan bahwa motivasi kerja dan kepuasan kerja erat hubungannya dalam berbagai teori motivasi namun keduanya memiliki perbedaan, motivasi kerja dan kepuasan kerja tidak identik satu sama lainnya. Hal ini menunjukkan bahwa motivasi kerja tidak selamanya berhubungan dengan kepuasan kerja. Tujuan umum penelitian ini adalah untuk memperoleh pengetahuan dan melakukan kajian secara ilmiah tentang pengaruh praktik kerja industri (PRAKERIN), informasi dunia kerja dan motivasi memasuki dunia kerja terhadap kesiapan kerja siswa.

\section{METODE PENELITIAN}

Pendekatan yang digunakan dalam penelitian ini adalah pendekatan kuantitatif, dimana data-data yang diperoleh berupa angka dan menggunakan analisis statistik. Jenis penelitian ini adalah deskriptif verifikatif. Menurut (Suharsimi Arikunto, 2010) penelitian deskriptif adalah penelitian yang dimaksudkan untuk menyelidiki keadaan, kondisi atau hal-hal yang sudah disebutkan, yang hasilnya dipaparkan dalam bentuk laporan penelitian. Sedangkan penelitian verifikatif menurut (Suharisimi Arikunto, 2010) merupakan penelitian yang bertujuan mengecek hasil penelitian lain. Penelitian verifikatif dimaksudkan untuk menguji kebenaran suatu hipotesis yang dilakukan melalui pengumpulan data di lapangan. Metode penelitian yang digunakan dalam penelitian ini adalah metode penelitian Explanatory Survey.

Populasi dalam penelitian ini adalah siswa kelas XII program keahlian otomatisasi tata kelola perkantoran di SMK Negeri se-kota Serang sebanyak 434 siswa dengan menggunakan sampel sebanyak 208 siswa, penentuan jumlah sampel peserta didik dilakukan melalui perhitungan dengan menggunakan rumus slovin. Teknik pengumpulan data yang digunakan untuk memperoleh data yang dibutuhkan menggunakan instrumen penelitian dalam bentuk kuesioner. Karena data yang digunakan dalam penelitian ini merupakan data primer dan data sekunder. Peneliti menggunakan studi lapangan (Field search) dengan memberikan instrumen penelitian berupa kuesioner yang berbentuk digital, karena pada masa Pandemic Covid-19 ini adanya larangan physical distancing dalam protokol kesehatan yang diberlakukan oleh pemerintah. Kuesioner yang berbentuk digital ini menggunakan salah satu produk dari google yaitu google form yang dapat diakses oleh seluruh siswa yang menjadi responden. Skala yang digunakan adalah skala Likert. Menurut (Sugiyono, 2019) Skala Likert digunakan untuk mengukur sikap, pendapat, dan presepsi seseorang atau sekelompok orang tentang fenomena sosial.

Metode analisis data dalam penelitian ini menggunakan analisis ststistik deskriptif, uji asumsi klasik, analisis linier berganda, koefisien determinasi, uji t dan uji $\mathrm{F}$ untuk menjawab rumusan masalah dan tujuan penelitian.

\section{HASIL DAN PEMBAHASAN PENELITIAN}

Hasil analisis deskriptif dalam penelitian ini menunjukan bahwa praktik kerja industri (PRAKERIN) siswa kelas XII program keahlian otomatisasi tata kelola perkantoran SMK Negeri se-kota Serang termasuk dalam kategori tinggi dilihat dari skor jawaban siswa diperoleh sebanyak 198 peserta didik (95\%) termasuk kedalam kategori tinggi, ini menunjukan bahwa pelaksanaan praktik kerja industri sangat efektif. Informasi dunia kerja siswa kelas XII program keahlian otomatisasi tata kelola perkantoran SMK Negeri se-kota Serang termasuk dalam kategori tinggi dilihat dari skor jawaban siswa diperoleh sebanyak 181 peserta didik (87\%) termasuk kedalam kategori tinggi, ini menunjukan bahwa kualitas informasi yang diterima oleh siswa sangat baik dan berkualitas. Motivasi memasuki dunia kerja siswa kelas XII program keahlian otomatisasi tata kelola 
4112 Pengaruh Pengalaman Praktik Kerja Industri (Prakerin), Informasi Dunia Kerja dan Motivasi Memasuki Dunia Kerja terhadap Kesiapan Kerja Siswa SMK - Agia Seriana Yusadinata, Amir Machmud, Budi Santoso

DOI: https://doi.org/10.31004/edukatif.v3i6.1318

perkantoran SMK Negeri se-kota Serang termasuk dalam kategori tinggi dilihat dari skor jawaban siswa diperoleh sebanyak 191 peserta didik (92\%) termasuk kedalam kategori tinggi, ini menunjukan bahwa para siswa memiliki motivasi kerja yang baik untuk memasuki dunia kerja. Kesiapan kerja siswa kelas XII program keahlian otomatisasi tata kelola perkantoran SMK Negeri se-kota Serang dalam kategori tinggi dilihat dari skor jawaban siswa diperoleh sebanyak 191 peserta didik (92\%) termasuk kedalam kategori tinggi, ini menunjukan bahwa para siswa memiliki tingkat kesiapan yang baik untuk siap terjun kedalam dunia kerja.

Penggunaan analisis linier berganda bertujuan untuk memerikasa dan memodelkan hubungan diantara pengalaman praktik kerja industri, informasi dunia kerja dan motivasi kerja terhadap kesiapan kerja siswa. Berikut ini adalah hasil analisis linier berganda menggunakan bantuan IBM SPSS for Windows 25.0 dapat dilihat pada tabel di bawah ini :

Tabel 2. Hasil Analisis Linier Berganda

\begin{tabular}{|c|c|c|c|c|c|c|c|}
\hline \multicolumn{8}{|c|}{ Coefficients $^{\mathbf{a}}$} \\
\hline & & & \multicolumn{2}{|c|}{$\begin{array}{l}\text { Unstandardized } \\
\text { Coefficients }\end{array}$} & \multirow{2}{*}{$\begin{array}{l}\text { Standardized } \\
\text { Coefficients } \\
\text { Beta }\end{array}$} & \multirow[b]{2}{*}{$\mathrm{t}$} & \multirow[b]{2}{*}{ Sig. } \\
\hline \multicolumn{2}{|c|}{ Model } & & B & Std. Error & & & \\
\hline \multirow[t]{4}{*}{1} & (Constant) & & 29,059 & 5,235 & & 5,551 & ,000 \\
\hline & $\begin{array}{l}\text { Praktik } \\
\text { Industri }\end{array}$ & Kerja & ,294 &, 056 & ,341 & 5,208 & ,000 \\
\hline & $\begin{array}{l}\text { Informasi } \\
\text { Kerja }\end{array}$ & Dunia & ,231 & ,099 & ,166 & 2,334 & ,021 \\
\hline & Motivasi K & & ,343 & 057 & ,363 & 6,015 & ,000 \\
\hline
\end{tabular}

a. Dependent Variable: Kesiapan Kerja

Berdasarkan tabel di atas, maka persamaan garis regresi dapat dinyatakan dalam persamaan sebagai berikut:

$\mathrm{Y}=29.059+0.294 X 1+0.231 X 2+0.343 X 3$

Persamaan tersebut menunjukkan bahwa nilai koefisien regresi $X 1$ sebesar 0.294 yang berarti nilai Praktik Kerja Industri (X1) meningkat satu satuan maka nilai Kesiapan Kerja (Y) akan meningkat 0.294 satuan dengan asumsi $X 2$ dan $X 3$ tetap, demikian juga nilai koefisien regresi $X 2$ sebesar 0.231 yang berarti jika nilai Informasi Dunia Kerja (X2) meningkat satu satuan maka nilai Kesiapan Kerja (Y) akan meningkat 0.231 satuan dengan asumsi $X 1$, dan $X 3$ tetap, demikian juga nilai koefisien regresi $X 3$ sebesar 0.343 yang berarti jika nilai Motivasi Kerja (X3) meningkat satu satuan maka nilai Kesiapan Kerja (Y) akan meningkat 0.343 satuan dengan asumsi $X 1$ dan $X 2$ tetap.

Pengujian secara parsial (Uji t) dilakukan untuk mengetahui pengaruh dari masing-masing varibel independen terhadap variabel dependen. secara terpisah, berikut ini hasil uji t menggunakan IBM SPSS for Windows 25.Odari setiap variabel independen terhadap variabel dependen.

Tabel 3. Hasil Uji t

\section{Coefficients $^{\mathbf{a}}$}

\begin{tabular}{|c|c|c|c|c|c|c|c|}
\hline \multirow{2}{*}{\multicolumn{2}{|c|}{ Model }} & & \multicolumn{2}{|c|}{$\begin{array}{l}\text { Unstandardized } \\
\text { Coefficients }\end{array}$} & \multirow{2}{*}{$\begin{array}{l}\text { Standardized } \\
\text { Coefficients } \\
\text { Beta }\end{array}$} & \multirow[b]{2}{*}{$\mathrm{t}$} & \multirow[b]{2}{*}{ Sig. } \\
\hline & & & $\bar{B}$ & Std. Error & & & \\
\hline \multirow[t]{2}{*}{1} & (Constant) & & 29,059 & 5,235 & & 5,551 & 000 \\
\hline & $\begin{array}{l}\text { Praktik } \\
\text { Industri }\end{array}$ & Kerja & 294 & ,056 & ,341 & 5,208 & ,000 \\
\hline
\end{tabular}


4113 Pengaruh Pengalaman Praktik Kerja Industri (Prakerin), Informasi Dunia Kerja dan Motivasi Memasuki Dunia Kerja terhadap Kesiapan Kerja Siswa SMK - Agia Seriana Yusadinata, Amir Machmud, Budi Santoso

DOI: https://doi.org/10.31004/edukatif.v3i6.1318

\begin{tabular}{ll|l|l|l|l}
\hline $\begin{array}{l}\text { Informasi } \\
\text { Kerja }\end{array}$ & Dunia, 231 &, 099 &, 166 & 2,334 &, 021 \\
\hline Motivasi Kerja $\quad, 343$ &, 057 &, 363 & 6,015 &, 000 \\
\hline
\end{tabular}

a. Dependent Variable: Kesiapan Kerja

Pengalaman praktik kerja industri berpengaruh positif terhadap kesiapan kerja siswa (H1) Variabel Pengalaman praktik kerja industri (X1) berpengaruh secara positif terhadap kesiapan kerja siswa (Y). Berdasarkan hasil uji $t$ diperoleh hasil thitung sebesar 5.208 dan ttabel sebesar 1.971 pada taraf signifikansi sebesar 5\% maka thitung lebih besar dari ttabel $(5.208>1.971)$ atau $\mathrm{p}(0.00<0.05)$. Hal ini menunjukan bahwa H0 ditolak dan H1 diterima yang artinya Variabel Pengalaman praktik kerja industri (X1) berpengaruh secara positif terhadap kesiapan kerja siswa (Y).

Informasi dunia kerja berpengaruh positif terhadap kesiapan kerja siswa (H2) Variabel Informasi dunia kerja (X2) berpengaruh secara positif terhadap kesiapan kerja siswa (Y). Berdasarkan hasil uji t diperoleh hasil thitung sebesar 2.334 dan ttabel sebesar 1.971 pada taraf signifikansi sebesar 5\% maka t hitung lebih besar dari ttabel $(2.334>1.971)$ atau $\mathrm{p}(0.021<0.05)$. Hal ini menunjukan bahwa H0 ditolak dan $\mathrm{H} 2$ diterima yang artinya Variabel Informasi dunia kerja (X2) berpengaruh secara positif terhadap kesiapan kerja siswa (Y).

Motivasi memasuki dunia kerja berpengaruh positif terhadap kesiapan kerja siswa (H3) Variabel Motivasi memasuki dunia kerja (X3) berpengaruh secara positif terhadap kesiapan kerja siswa (Y). Berdasarkan hasil uji t diperoleh hasil thitung sebesar 6.015 dan tabel sebesar 1.971 pada taraf signifikansi sebesar 5\% maka thitung lebih besar dari t tabel $(6.015>1.971)$ atau $\mathrm{p}(0.00<0.05)$. Hal ini menunjukan bahwa H0 ditolak dan H3 diterima yang artinya Variabel Motivasi memasuki dunia kerja (X3) berpengaruh secara positif terhadap kesiapan kerja siswa $(\mathrm{Y})$.

Uji F merupakan pengujian secara simultan bertujuan untuk mengetahui variabel independen terhadap secara bersama-sama mempengaruhi variabel dependen. Berikut ini adalah hasil dari pengujian secara Simultan (Uji F) menggunakan IBM SPSS for Windows 25.0.

Tabel 4. Hasil Uji F

\begin{tabular}{|c|c|c|c|c|c|c|}
\hline ANOV & & & & & & \\
\hline Model & & $\begin{array}{ll}\text { Sum } & \text { of } \\
\text { Squares }\end{array}$ & df & Mean Square & $\mathrm{F}$ & Sig. \\
\hline 1 & Regression & 11097,919 & 3 & 3699,306 & 86,897 &, $000^{\mathrm{b}}$ \\
\hline & Residual & 8684,537 & 204 & 42,571 & & \\
\hline & Total & 19782,457 & 207 & & & \\
\hline Dep & ndent Variab & :Kesiapan_Kerja & & & & \\
\hline
\end{tabular}

Variabel pengalaman praktik kerja industri, informasi dunia kerja dan motivasi memasuki dunia kerja secara bersama-sama berpengaruh positif terhadap kesiapan kerja siswa. Berdasarkan hasil uji $\mathrm{F}$ diperoleh hasil $F_{\text {hitung }}$ sebesar 86.897 dan $F_{\text {tabel }}$ sebesar 1.971 pada taraf signifikansi sebesar $5 \%$ maka $F_{\text {hitung }}$ lebih besar dari $\mathrm{F}_{\text {tabel }}(86.897>2.648)$ atau $\mathrm{p}(0.00<0.05)$. Hal ini menunjukan bahwa $\mathrm{H}_{0}$ ditolak dan $\mathrm{H}_{4}$ diterima yang artinya Variabel Pengalaman praktik kerja industri $\left(\mathrm{X}_{1}\right)$, informasi dunia kerja $\left(\mathrm{X}_{2}\right)$ dan motivasi memasuki dunia kerja $\left(\mathrm{X}_{3}\right)$ secara bersama-sama berpengaruh positif terhadap kesiapan kerja siswa $(\mathrm{Y})$.

Besarnya pengaruh praktik kerja industri $\left(\mathrm{X}_{1}\right)$, informasi dunia kerja $\left(\mathrm{X}_{2}\right)$ dan motivasi kerja siswa $\left(\mathrm{X}_{3}\right)$, terhadap kesiapan kerja siswa (Y) dapat diketahui dengan menggunakan analisis koefisen determinasi yang diperoleh dengan mengkuadratkan koefisien korelasinya. 
4114 Pengaruh Pengalaman Praktik Kerja Industri (Prakerin), Informasi Dunia Kerja dan Motivasi Memasuki Dunia Kerja terhadap Kesiapan Kerja Siswa SMK - Agia Seriana Yusadinata, Amir Machmud, Budi Santoso

DOI: https://doi.org/10.31004/edukatif.v3i6.1318

Tabel 5. Koefisien Determinasi

\begin{tabular}{|c|c|c|c|c|}
\hline \multicolumn{5}{|c|}{ Model Summary } \\
\hline Model & $\mathrm{R}$ & R Square & Adjusted R Square & $\begin{array}{l}\text { Std. Error of the } \\
\text { Estimate }\end{array}$ \\
\hline 1 &, $749^{\mathrm{a}}$ & ,561 & ,555 & 6,525 \\
\hline
\end{tabular}

a. Predictors: (Constant), Praktik Kerja Industri, Informasi Dunia Kerja, Motivasi Kerja,

b. Dependent Variable: Kesiapan Kerja

Berdasarkan hasil analisis dengan menggunakan IBM SPSS for Windows 25.0, harga koefisien determinasi $\mathrm{X}_{1}, \mathrm{X}_{2}$ dan $\mathrm{X}_{3}$ terhadap $\mathrm{Y}(R 2 y 12)$ sebesar 0.561 . Hal ini menunjukkan bahwa variabel pengalaman prakerin, informasi dunia kerja dan motivasi kerja memiliki kontribusi pengaruh terhadap kesiapan kerja siswa sebesar $56.10 \%$ sedangkan $43,90 \%$ dipengaruhi oleh variabel lain yang tidak termasuk ke dalam penelitian.

\section{Pengaruh pengalaman praktik kerja industri (PRAKERIN) terhadap kesiapan kerja siswa kelas XII program keahlian otomatisasi tata kelola perkantoran SMK Negeri se-kota Serang}

Pengalaman Prakerin berpengaruh positif dan signifikan terhadap kesiapan kerja. Diperoleh hasil nilai koefisien regresi $X 1$ sebesar 0.294 yang berarti nilai Praktik Kerja Industri $(X 1)$ meningkat satu satuan maka nilai Kesiapan Kerja (Y) akan meningkat 0.294 satuan. Dalam penelitian ini juga dilakukan uji signifikansi menggunakan uji t untuk menjawab hipotesis. Berdasarkan hasil uji t diperoleh hasil thitung sebesar 5.208 dan ttabel sebesar 1.971 pada taraf signifikansi sebesar 5\% maka t hitung lebih besar dari t tabel $(5.208>1.971)$ atau p $(0.00<0.05)$. Hal ini menunjukan bahwa H0 ditolak dan $\mathrm{H} 1$ diterima yang artinya Variabel Pengalaman praktik kerja industri (X1) berpengaruh secara positif terhadap kesiapan kerja siswa (Y).

Hasil dalam penelitian ini sejalan dengan hasil penelitian yang dilakukan oleh Abur (Mustikawanto, 2019) yang menyatakan bahwa terdapat pengaruh positif dan signifikan antara pengalaman prakerin terhadap kesiapan kerja. Pengalaman prakerin siswa sangat bermanfaat guna mempersiapkan diri siswa SMK untuk memasuki dunia kerja. Pengalaman yang diperoleh selama prakerin dapat memberikan wawasan mengenai dunia kerja dan wirausaha secara nyata. Pengalaman prakerin akan memberikan gambaran secara penuh tentang siklus industri yang secara langsung merupakan aplikasi dan implementasi dari pembelajaran kelompok wajib nasional, wajib kewilayahan, dan peminatan baik $\mathrm{C} 1, \mathrm{C} 2$ dan $\mathrm{C} 3$ sesuai dengan kompetensi keahlian.

\section{Pengaruh informasi dunia kerja terhadap kesiapan kerja siswa kelas XII program keahlian otomatisasi tata kelola perkantoran SMK Negeri se-kota Serang}

Pengalaman informasi dunia kerja berpengaruh positif dan signifikan terhadap kesiapan kerja. Diperoleh hasil nilai koefisien regresi X2 sebesar 0.231 yang berarti jika nilai Informasi Dunia Kerja (X2) meningkat satu satuan maka nilai Kesiapan Kerja (Y) akan meningkat 0.231 satuan. Dalam penelitian ini juga dilakukan uji signifikansi menggunakan uji t untuk menjawab hipotesis. Berdasarkan hasil uji t diperoleh hasil t hitung sebesar 2.334 dan $\mathrm{t}$ tabel sebesar 1.971 pada taraf signifikansi sebesar 5\% maka t hitung lebih besar dari t tabel $(2.334>1.971)$ atau $\mathrm{p}(0.021<0.05)$. Hal ini menunjukan bahwa H0 ditolak dan $\mathrm{H} 2$ diterima yang artinya Variabel Informasi dunia kerja (X2) berpengaruh secara positif terhadap kesiapan kerja siswa (Y).

Hasil ini sejalan dengan hasil penelitian dari (Kusnaeni \& S, 2016) yang menunjukan bahwa informasi yang diperoleh siswa dari berbagai sumber dan pihak dapat mendukung dalam mempersiapakan diri untuk 
4115 Pengaruh Pengalaman Praktik Kerja Industri (Prakerin), Informasi Dunia Kerja dan Motivasi Memasuki Dunia Kerja terhadap Kesiapan Kerja Siswa SMK - Agia Seriana Yusadinata, Amir Machmud, Budi Santoso

DOI: https://doi.org/10.31004/edukatif.v3i6.1318

bekerja sehingga dapat membantu siswa dalam mempersiapkan diri memasuki dunia kerja. Hasil dalam penelitian ini sejalan dengan hasil penelitian yang dilakukan oleh (Kusnaeni \& S, 2016) menunjukan bahwa informasi yang diperoleh siswa dari berbagai sumber dan pihak dapat mendukung dalam mempersiapakan diri untuk bekerja sehingga dapat membantu siswa dalam mempersiapkan diri memasuki dunia kerja.

Informasi dunia kerja dapat mempengaruhi proses pengambilan keputusan siswa dalam menentukan tujuan arah karirnya pada masa mendatang dan informasi yang diterima oleh siswa diharapkan bisa dijadikan sebagai suatu gambaran dalam melihat peluang-peluang yang ada dan dapat membantu siswa untuk menghadapinya. Sumber informasi dunia kerja dapat diperoleh dari berbagai sumber, baik yang disediakan oleh sekolah maupun dari luar sekolah. Bagi calon tenaga kerja lulusan dari SMK, memiliki informasi dunia kerja yang banyak dapat memberikan kemudahan dalam mengetahui kondisi dunia kerja. Hal ini dapat menjadikan suatu dorongan agar para lulusan SMK dapat lebih meningkatkan tingkat Readiness dalam dirinya sendiri.

\section{Pengaruh motivasi kerja terhadap kesiapan kerja siswa kelas XII program keahlian otomatisasi tata kelola perkantoran SMK Negeri se-kota Serang}

Pengalaman motivasi kerja berpengaruh positif dan signifikan terhadap kesiapan kerja. Diperoleh hasil nilai koefisien regresi X3 sebesar 0.343 yang berarti jika nilai Motivasi Kerja (X3) meningkat satu satuan maka nilai Kesiapan Kerja (Y) akan meningkat 0.343 satuan. Dalam penelitian ini juga dilakukan uji signifikansi menggunakan uji t untuk menjawab hipotesis. Berdasarkan hasil uji t diperoleh hasil t hitung sebesar 6.015 dan t tabel sebesar 1.971 pada taraf signifikansi sebesar 5\% maka t hitung lebih besar dari $t$ tabel $(6.015>1.971)$ atau $\mathrm{p}(0.00<0.05)$. Hal ini menunjukan bahwa H0 ditolak dan H3 diterima yang artinya Variabel Motivasi memasuki dunia kerja (X3) berpengaruh secara positif terhadap kesiapan kerja siswa (Y). Hasil dalam penelitian ini sejalan dengan hasil penelitian yang dilakukan oleh Abur Mustikawanto (2019) yang menyatakan bahwa terdapat pengaruh positif dan signifikan motivasi kerja terhadap kesiapan kerja.

Motivasi kerja siswa dalam diri siswa SMK sangatlah penting karena dengan motivasi yang tinggi dapat mendorong siswa untuk lebih dinamis dalam meningkatkan pengaturan atau kemampuan baik dari segi informasi, kemampuan dan perspektif kerja serta budaya modern, siswa akan berusaha secara jujur untuk mengatur diri mereka untuk berubah menjadi angkatan kerja yang dapat diandalkan sesuai dengan keahlian yang dimiliki, sehingga siswa lebih siap bekerja atau menjadi pebisnis.

Tingginya motivasi belajar siswa akan mempengaruhi keinginan yang lebih tinggi untuk berimajinasi dan meningkatkan yang dimiliki oleh siswa sehingga mendorong pihak SMK untuk meningkatkan kompetensi SDM,(Putra, 2019) kerangka kerja dan latihan ukuran pembelajaran, baik melalui penjemputan fasilitas industri, pertunjukan industri, techno park, dan lain sebagainya. Motivasi belajar yang tinggi akan berdampak pada motivasi kerja, motivasi kerja seseorang akan muncul atau terlihat melalui tanggung jawab melakukan kerja, prestasi atau kompetensi yang dicapainya, pengembangan dirinya serta kemampuan dalam bertindak. Motivasi kerja akan nampak pula diantaranya selalu bertanggung jawab atas semua pekerjaan yang dilakukannya, selalu berusaha mencapai prestasi kerja sebaik mungkin, mandiri, tekun, berwawasan luas dalam lingkup pekerjaannya, sarat dengan kreativitas dan mengembangkan keahlian pekerjaannya.

\section{Pengaruh pengalaman praktik kerja industri (PRAKERIN), informasi dunia kerja dan motivasi kerja terhadap kesiapan kerja siswa kelas XII program keahlian otomatisasi tata kelola perkantoran SMK Negeri se-kota Serang}

Pengalaman praktik kerja industri, informasi dunia kerja dan motivasi memasuki dunia kerja secara bersama-sama berpengaruh positif terhadap kesiapan kerja siswa. Berdasarkan hasil uji $\mathrm{F}$ diperoleh hasil $\mathrm{F}$ hitung sebesar 86.897 dan $\mathrm{F}$ tabel sebesar 1.971 pada taraf signifikansi sebesar 5\% maka $\mathrm{F}$ hitung lebih besar 
4116 Pengaruh Pengalaman Praktik Kerja Industri (Prakerin), Informasi Dunia Kerja dan Motivasi Memasuki Dunia Kerja terhadap Kesiapan Kerja Siswa SMK - Agia Seriana Yusadinata, Amir Machmud, Budi Santoso

DOI: https://doi.org/10.31004/edukatif.v3i6.1318

dari F tabel $(86.897>2.648)$ atau $\mathrm{p}(0.00<0.05)$. Hal ini menunjukan bahwa $\mathrm{H} 0$ ditolak dan $\mathrm{H} 4$ diterima yang artinya Variabel Pengalaman praktik kerja industri (X1), informasi dunia kerja (X2) dan motivasi memasuki dunia kerja (X3) secara bersama-sama berpengaruh positif terhadap kesiapan kerja siswa (Y). Harga koefisien determinasi $X 1, X 2$ dan $X 3$ terhadap $\mathrm{Y}(R 2 y 12)$ sebesar 0.561 . Hal ini menunjukkan bahwa variabel pengalaman prakerin, informasi dunia kerja dan motivasi kerja memiliki kontribusi pengaruh terhadap kesiapan kerja siswa sebesar 56.10\% sedangkan 43,90\% dipengaruhi oleh variabel lain yang tidak termasuk ke dalam penelitian.

Terbuktinya hipotesis keempat ini dapat memberikan informasi bahwa pengalaman prakerin, informasi dunia kerja dan motivasi kerja secara bersama-sama mempunyai pengaruh positif dan signifikan terhadap kesiapan kerja. Oleh karena itu pelaksanaan prakerin, informasi dunia kerja dan motivasi kerja secara bersama-sama harus diperhatikan untuk meningkatkan kesiapan kerja peserta didik. Semakin baik efektiftas pelaksanaan prakerin, kualitas informasi dunia kerja yang diberikan dan motivasi kerja yang dimiliki oleh peserta didik maka akan berpengaruh sangat besar terhadap kesiapan kerja peserta didik dalam menghadapi dunia kerja.

\section{KESIMPULAN}

Simpulan yang dapat ditarik dalam penelitian ini adalah praktik kerja industri (PRAKERIN), informasi dunia kerja dan motivasi memasuki dunia kerja siswa kelas XII program keahlian otomatisasi tata kelola perkantoran SMK Negeri se-kota Serang termasuk dalam kategori tinggi. Pengalaman praktik kerja industri, informasi dunia kerja dan motivasi memasuki dunia kerja berpengaruh positif dan signifikan terhadap kesiapan kerja siswa baik secara parsial maupun simultan serta memiliki kontribusi pengaruh sebesar 56.10\% sedangkan 43,90\% dipengaruhi oleh variabel lain yang tidak termasuk ke dalam penelitian. Semakin tinggi dan baik program praktik kerja industri (PRAKERIN), informasi dunia kerja dan motivasi kerja siswa semakin tinggi dan baik pula kesiapan kerja yang akan dimiliki oleh siswa.

\section{DAFTAR PUSTAKA}

Ahkyat, F. (2019). The Effect Of Industrial Work Practices On Students 'Readiness At The High School Of Vocational Partners Pt. Astra Daihatsu Motor. International Journal Of Innovative Technology And Exploring Engineering (Ijitee ), 9(2), 2278-3075.

Ahmad, S. A. (2020). The Relationship Between Motivation And Student Work Readiness At Smkn 1 Lubuk Sikaping. Jurnal Imiah Pendidikan Dan Pembelajaran, 4(1), 2615-609.

Arikunto, Suharisimi. (2010). Prosedur Penelitian. Pt. Rineka Cipta.

Arikunto, Suharsimi. (2010). Prosedur Penelitian; Suatu Pendekatan Praktik. Rineka Cipta.

Brady, R. P. (2009). Work Readiness Inventory Administrator's Guide. Ournal Of International, 5(1), 141160.

Bukit, M. (2014). Staretgi Dan Inovasi Pendidika Kejuruan Dari Kompetensi Ke Kompetensi. Alfa Beta Bandung.

Hasibuan, M. (2007). Organisasi\&Motivasi Dasar Peningkatan Produktivitas. Jakarta: Bumi Aksara. (2007). Manajemen Sumber Daya Manusia. Jakarta: Bumi Aksara. Bumi Aksara.

Hilmi, A. M., \& Lukmantoro, D. (2019). Relationship Between Internship Experience, Self- Concept And Student's Commitment To The Readiness Of The Automotive Field Work. International Conference On Agriculture, Social Sciences, Education, Technology And Health (Icasseth 2019). 
4117 Pengaruh Pengalaman Praktik Kerja Industri (Prakerin), Informasi Dunia Kerja dan Motivasi Memasuki Dunia Kerja terhadap Kesiapan Kerja Siswa SMK - Agia Seriana Yusadinata, Amir Machmud, Budi Santoso

DOI: https://doi.org/10.31004/edukatif.v3i6.1318

Johnson, E. B. (2007). Contextual Teaching And Learning, Terjemahan Ibnu Setiawan. Mlc.

Kian, T. S. (2014). Job Satisfaction Andmotivation: What Are The Difference Among These Two? Europen Journal Of Business And Social Sciences, 3(2).

Komang. (2014). Efektivitas Teori Karierholland Melalui Layanan Informasi Untuk Meningkatkan Pemahaman Diri Terhadap Kesiapan Kerja Siswa. Jurnal Online Jurusan Bimbingan Konseling. Singaraja, 2(1).

Kusnaeni, Y., \& S, M. (2016). Pengaruh Persepsi Tentang Praktik Kerja Lapangan, Informasi Dunia Kerja Dan Motivasi Memasuki Dunia Kerja Terhadap Kesiapan Kerja Siswa Smk. Journal Of Economic Education, 5(1).

Mustikawanto, A. (2019). Effect Of Competency, Work Motivation, Industrial Work Experience And Facilities On The Readiness Of Work For Senior High School Graduates In Electro Expertise Programs Invotec. Innovation Of Vocational Technology Education., 15(1), 1-4.

Novitasari, F. (2013). Pengaruh Program Pengalaman Lapangan Terhadap Kesiapan Mahasiswa Prodi Ekonomi Fkip Uns Menjadi Tenaga Pendidik. Jurnal Pendidikan Ekonomi (Jupe), 1(3).

Putra, P. (2019). Implementasi Sikap Disiplin Anak Di Lembaga Madrasah Ibtidaiyah (Mi) Dalam Membentuk Pengembangan Moral. Primary: Jurnal Keilmuan Dan Kependidikan Dasar, 11(1), 35. Https://Doi.Org/10.32678/Primary.V11i01.1293

Sugiyono. (2019). Metode Penelitian Kunatitatif Kualitatif Dan R\&D. Alfabeta.

Sukardi, D. K. (2003). Bimbingan Karir Di Sekolah-Sekolah. Denpasar: Bumi Aksara. Bumi Aksara.

Uno, H. B. (2014). Teori Motivasi Dan Pengukuranya. Bumi Aksara.

Winkel, W. ., \& Sri, H. M. (2007). Bimbingan Konseling Di Institusi Pendidikan. Media Abadi. 